\title{
TATÁRJÁRÁS KORI KINCSLELET AZ ABAÚJVÁRI ISPÁNI VÁRBÓL
}

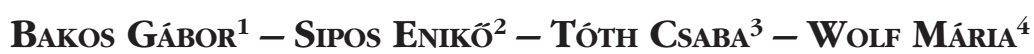 \\ Magyar Régészet 9. évf. (2020), 4. szám, pp. 52-61. doi: https://doi.org/10.36245/mr.2020.4.3
}

A tatárjárás régészeti emlékeivel foglakozó kutatók már régen felfigyeltek arra, hogy az ország különbözö részein kincsleletek kerülnek elö, amelyek érmeket, ékszereket és más értékes tárgyakat tartalmaznak, és ezeket a bennük található pénzek alapján az 1241-1242-es pusztításhoz kapcsolhatjuk. Más helyeken vastárgyakat, elsösorban mezögazdasági eszközöket rejtettek el, de az esetek döntö többségében ezek is véletlenszerüen kerültek napvilágra, nem régészeti ásatáson. Ezért is különleges az a lelet, amely 2019. júliusában került elö az abaújvári Árpád-kori ispáni várban. Az érmek, ékszerek és a rendkívüli leletek, például az aranyszállal készített textilmaradványok, valamint a vár jelentősége indokolja, hogy kutatás első eredményeit rövid idön belül bemutassuk, bár a leletanyag feldolgozása még folyamatban van. ${ }^{5}$

\section{A LELÖHELY}

Abaújvár vára a mai szlovák-magyar határon, a Zempléni hegység előterében, közvetlenül a Hernád folyó partján, egy alacsony, különálló dombon épült (1. kép). A csaknem teljesen ép sáncok 3,9 hektáros területet ölelnek körül, legmagasabb pontjuk a Hernád fölé 15 méterrel, a várbelső fölé 5 méterrel magasodik. A vár egyetlen bejárata kelet felől nyílott, itt egy, mára már erősen betöltődött árok is védelmezte (2. kép).

A vár a történeti Abaúj megye központja, maga a megye pedig egyike volt a Szent István által alapítottaknak, és a 11. század első harmadában már fennállt (GYÖRFFY 1977, 209; KRISTó 1988, 400). Létrejöttében meghatározó jelentőségű volt az Orosz- és Lengyelország felé vezető, igen fontos, észak-déli irányú hadi és kereskedelmi út, amelyet a középkorban „Abanagyúta”, „Nagy út”, illetve „Királyúta” néven említenek forrásaink (GYÖRFFY, 1963, 53). Ugyanakkor Abaúj az Árpád-korban határ megye volt, így a vár elsődleges feladata az északi határok védelme volt. Ezzel kapcsolatos az egyik legkorábbi említése is: 1068-ban egy határőréről név szerint emlékeztek meg a források (GYÖRFFY 1963, 45; KRISTÓ 1988, 400). A várat a 11. századi trónviszályokkal és pogánylázadásokkal kapcsolatban is többször említik krónikáink, 1046-ban pl. az Oroszországból hazatérő András herceget Újvárban ismerték el királyuknak a magyar urak. András ez év szeptemberében itt tartózkodott seregeivel (SRH I. 337). A vár a 11-13. századi Magyar Királyság egyik legfontosabb központja volt, amely már a 19. században is felkeltette a szakemberek érdeklődését. Az ekkor folytatott úttörő kutatások után 1974-1981 között Gádor Judit végzett ásatásokat a várban. Ennek során a sáncokról, illetve a vár belsejében elhelyezkedő templomról és a körülötte fekvő temetőről nyertünk adatokat.

A várfalakat jelentő fa-föld szerkezetű sáncok egy Kr. u. 3-4. századi településre épültek a 11. század első felében. A sánc vázát fa szerkezet alkotta, amelyet jórészt megmunkálatlan fatörzsekből hoztak létre. A gömbfákat egymást keresztezve, máglyarakás-szerűen rakták egymásra. Az így létrejött szabálytalan és váltakozó méretű rekeszek közeit földdel töltötték fel. A sánc eredeti szélessége 23 méter, magassága pedig - a jelenlegi 5 méterrel szemben - 9 méter lehetett. Feltártak továbbá a földsánc tetején, annak középvonalába építve egy kőfalmaradványt is. Ennek szélessége 4, magassága 0,5 méter volt (GÁdOR \& NovÁKI 1976a, 37-47; GÁDOR \& NovÁKi 1976b, 425-434; GÁDOR \& NovÁKi 1980, 43-76).

\footnotetext{
Herman Ottó Múzeum, Miskolc. E-mail: b.gabor@hotmail.com

Magyar Nemzeti Múzeum, Budapest. E-mail: siposeni@gmail.com

Magyar Nemzeti Múzeum, Budapest. E-mail: toth.csaba@hnm.hu

SZTE BTK Régészeti Tanszék, Szeged. E-mail: wolfmaria55@gmail.com

5 A tanulmány a Nemzeti Kutatási Fejlesztési és Innovációs Hivatal támogatásával a „Tatárjárás Magyarországon és a mongol hódítás eurázsiai összefüggései” című pályázat (K 128 880) keretében készült. A kincs előkerülésében és feldolgozásában végzett kitartó, és áldozatos munkájáért köszönettel tartozunk a Herman Ottó Múzeum Civil Fémkeresős Önkénteseinek, Bánfalvy Ferencnek, Kozmáné Bányi Juditnak, valamint Sáfrány Andrásnénak, a Herman Ottó Múzeum munkatársainak, és végül, de nem utolsó sorban a helyi lelkes lokálpatriótáknak, akik mindvégig segítették a munkánkat.
} 
Bakos Gábor et al. • Tatárjárás kori kincslelet az abaújvári ispáni várból

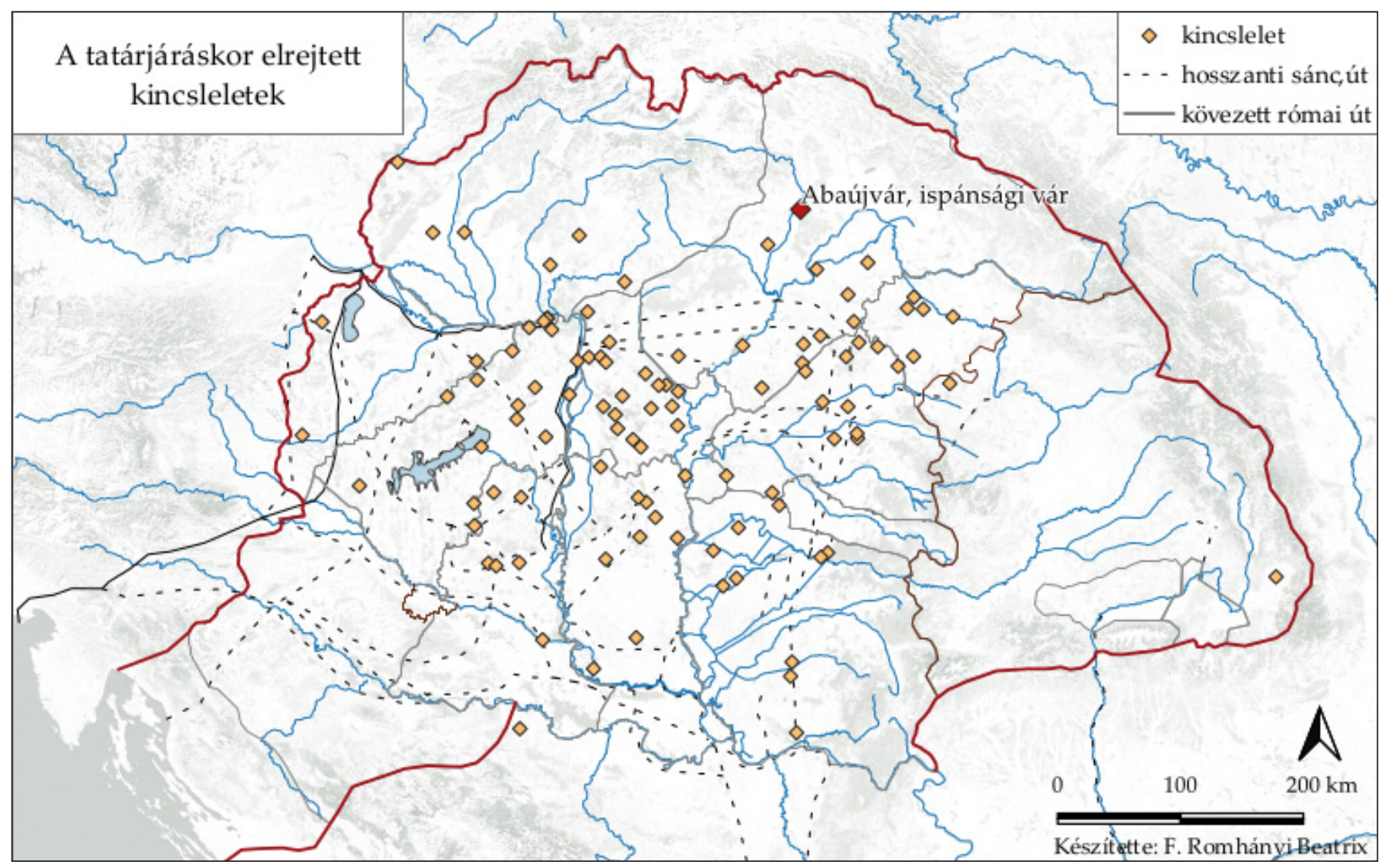

1. kép. Az abaújvári vár és a tatárjáráskori kincsleletek a középkori Magyarország területén

A várbelsőben egy nagyméretü, a 11. század második felére keltezhető templom is előkerült, amelyről feltehető, hogy a megye egyházi életét irányító esperes székhelye volt. Ezt látszik igazolni a templom körüli temetőből napvilágot látott díszes, egyházi személyre utaló, a 11-12. század fordulójára keltezhető sírkő is, amely az első esperes sírját fedhette. A templom körül sok száz síros temetőrészlet látott napvilágot, amelyet a sírokból előkerült leletek alapján a 11-14. század között használtak (GÁDOR 1980, 443-450). A település legkorábbi leletei a 11. századból valók, korukat nem utolsó sorban az I. András (1046-1061) uralkodásának elején vert ezüstpénz jelzi.

Az ásatások egyik legértékesebb lelete egy bronzlemezböl készült, kör alakú pecsétlö, billog volt. Elölapján negatív vésetủ ábrázolás, bal kezében keskeny pajzsot, jobbjában pedig hosszú nyélre szerelt bárdot tartó férfi látható. A középen elhelyezkedő alak körül Sigillu Lazari Iudices, azaz Lázár bíró pecsétje körirat olvasható. A billog a 12. század második felére datálható (GÁDOR, 1988, 129-136; WoLf, 1999, 288, Kat. 48).

Már ezen az ásatáson is előkerült egy mezőgazdasági eszközökből, két sarlóból, két ásóvasalásból és egy szőlőmetszőkésből álló, elrejtett leletegyüttes, amelyet a 12-13. századra keltezhetünk (GÁDOR \& NovÁKi 1976a, 40-45; GÁdor \& NovÁKi 1976b, 431-434; MÜLLER 1982, 25-26). Ez a kutatás azonban 1981-ben félbeszakadt, éppen a várbelső feltárása maradt el. Pedig a mai Magyarország területén csak kevés olyan korai központunk van, amelynek belső területe szabadon kutatható. Így az abaújvári vár belsejének további kutatása már csak azért is kulcsfontosságú volt, mert ettől várhatjuk a 11-13. századi központok szerepének, mindennapi életének megismerését.

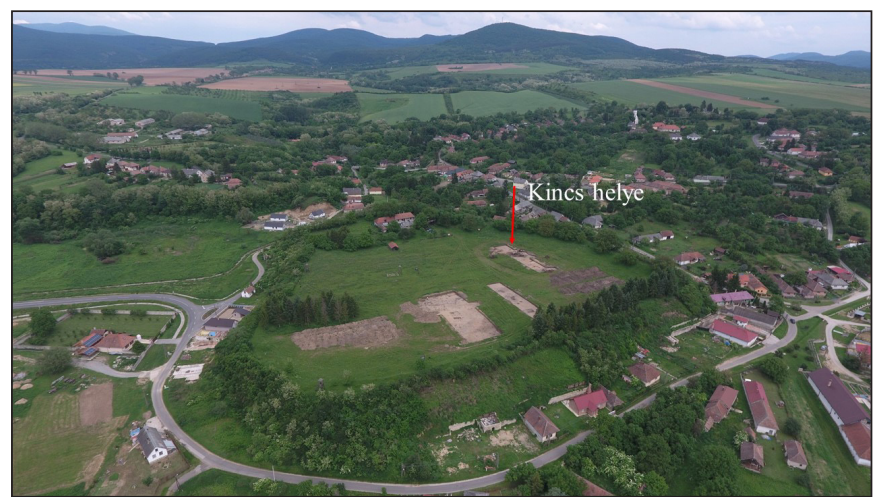

2. kép. Az abaújvári vár (Balogh Árpád felvétele) 
Bakos Gábor et al. • Tatárjárás kori kincslelet az abaújvári ispáni várból

Az újabb kutatásokra 2019-ben, az Árpád-ház program keretén belül nyílt lehetőségünk. Ekkor 2270 $\mathrm{m}^{2}$-en összesen 153 objektumot tártunk fel, melynek során több korszakba tartozó objektum látott napvilágot. Ezek túlnyomó többsége az Árpád-korból származik. Közülük a legjelentősebb egy kőalapozású, nagyméretü palotaépület, melyhez egy oszlopcsarnok is tartozott. A palota keleti alapfalának bontásakor két érem, egy 12. századi anonim denár, valamint egy, III. Béla által kibocsátott rézpénz látott napvilágot. Ez valószínúvé teszi, hogy a palota a 12. században épült.

\section{A KINCS}

Az ásatás során nagy mennyiségü fémtárgyat találtunk. Ez részben annak köszönhetö, hogy a Herman Ottó Múzeum fémkereső müszeres önkéntesei a kezdetektől folyamatosan részt vettek a munkában. Ezért is tartjuk nagy jelentőségünek a múzeumok munkája iránt aktívan érdeklődők és a régészek közötti összefogást. Módszertani szempontból is fontos hangsúlyozni a fémkereső müszer folyamatos használatát, hiszen egy ennyire sürün és több korszakon át intenzíven lakott területen rengeteg kisebb-nagyobb, változó mélységben elhelyezkedő, vegyes korú és anyagú lelet található.

A kincs megtalálása során először több, részben összetapadt, vagy jellegzetes zöld tapadásfolttal elökerülő érmére lettünk figyelmesek egy körülbelül $5 \times 8$ méteres körzetben. Az érmék mellett számos recens fémtárgy, valamint változatos méretű vastárgy jelét észleltük. Az egyre több érme előkerülése arra engedett következtetni, hogy egy részben vagy teljesen szétszántott, esetleg egyéb módon bolygatott éremlelettel állunk szemben, amelynek a magja szerencsés esetben még ép állapotban lehet az egykori mezőgazdasági müvelési mélység alatt. A zavaró fémjelek eltávolítását követően a lelet magjának helye pontosan meghatározható volt és bontása szakszerüen megkezdődhetett. A feltárás első fázisa során világossá vált, hogy a sekély gödörbe rejtett edény szájának egy részét megbolygatta egy eke, és felrántotta azokat az érmeket, amelyekre a lelet közvetlen környezetében először figyelmesek lettünk. A kincs helyének tisztázására egy szelvényt nyitottunk, ahol megtaláltuk a kincset rejtő fazék pontos helyét, valamint azt az eszközt is, amivel a fazekat elásták. Bár a fazék összetört, darabjait össze tudtuk gyüjteni, és így az edényt restaurálni lehetett. A tárgyak egy része szétszóródott, de a fémkeresőzés és az ásatás révén sikerült a kincset teljes egészében megmentenünk.

A lelet összesen 890 éremből, 4 ezüst és egy bronzcsatból, 2 ezüst és 2 arany gyürüből, 2 pár ép ezüst fülbevalóból és további három ezüst, csepp alakú fülbevaló-részből, egy ezüst, feltehetően fülbevalóhoz tartozó karikából, négy ékköves aranygombból, egy hegyikristály gyürü-, vagy függőbetétböl, egy erősen kopott római ezüstpénzből, egy liliomos végződésü, kisméretü tárgytöredékből, valamint egy aranyszállal szőtt textil maradványából állt (3. kép). A vegyes kincsleletben előkerült pénzek összetétele a tatárjárás kori leletekével egyezik, amelyek általában egyaránt tartalmaznak magyar és külföldi vereteket (Тóтн 2007; V. SzÉKELY 2014). ${ }^{6}$ Jelen esetben ezek aránya kb. 70:30 a magyar érmék javára. A magyar anyag legkorábbi vereteit II. András (1205-1235) két denára (H276) jelenti, ezen kívül a lelet tartalmazott még öt, különféle típusú IV. Béla (1235-1270) brakteátát (H191/4 db, H192/140 db, H195/114 db, H199/24 db, H200/24 db), illetve 302 példányt a szintén IV. Béla idején vert ezüstdenárokból (H69), valamint további nyolc, jelenleg még pontosan meg nem határozható ezüstpénzt. A külföldi veretek is a korszakban megszokott összetételt képviselik. Túlnyomó többségük az ún. friesachi denárok körébe tartozik, zömében jól azonosítható hivatalos veretek, de előfordulnak utánzatok is. A friesachi denárok ere-

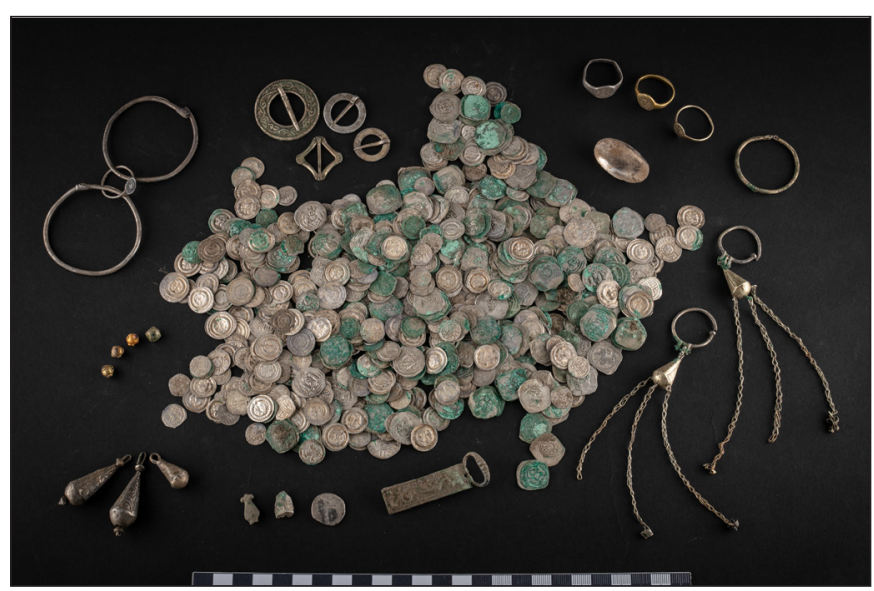

3. kép. A kincslelet restaurálás elött (Baranczó Benedek felvétele)

${ }^{6}$ A külföldi veretek meghatározásáért Tóth Szilárdnak tartozunk köszönettel. 
detileg a salzburgi érsekek által a karintiai Friesach városában a 12. század első felétől - a kölni denárok mintájára - vert, kiváló minőségü ezüstpénzek voltak. Később ez az elnevezés az eredeti friesachiak mintájára más világi és egyházi pénzverő hatóságok - pl. karintiai és stájer hercegek, andesch-merani grófok, gurki és bambergi püspökök, aquilejai pátriárkák - által a 12-13. század folyamán, föként Karintia és Krajna területén fekvő pénzverdékben kibocsátott denárok gyüjtőfogalmává vált. Leletünkben a legkorábbi darabok a 12. század utolsó harmadából, az ún. Eriacensis-periódus időszakából származnak, valószínüleg Adalbert salzburgi érsek verette őket 1170-1200 között. Legnagyobb mennyiségben II. András és IV. Béla kortársai, II.

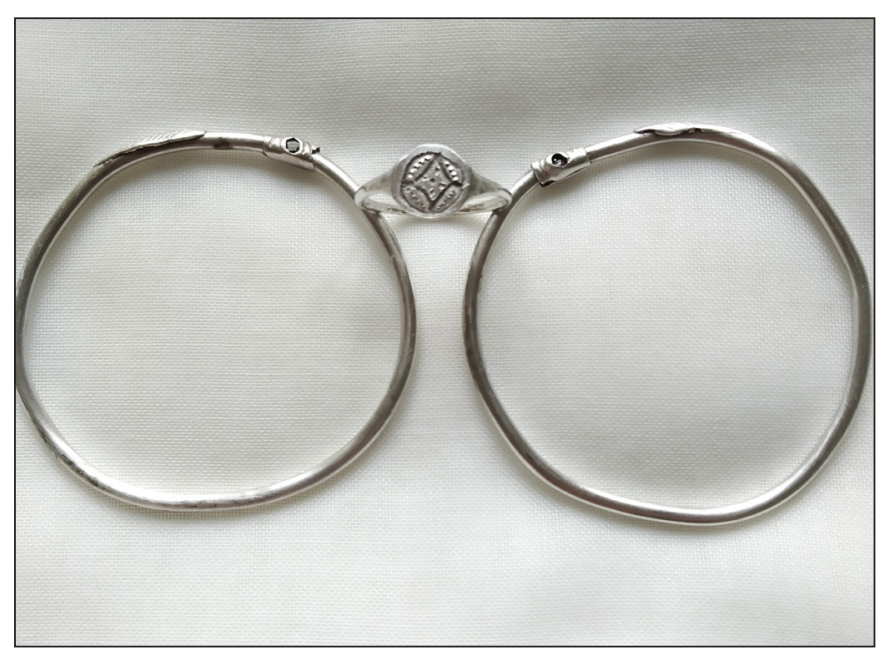

4. kép. A nielló díszes nöi gyürüvel összekapcsolt köpüs karikák (Kozmáné Bányi Judit felvétele) Eberhard salzburgi érsek (1200-1246), Bernhard karintiai herceg (1202-1256), továbbá Berthold aquilejai pátriárka (1218-1251) pénzeit tartalmazza. Ezeken kívül egy-egy kisebb pénzverde termékeit is megtaláljuk benne, általában egy-egy példányban, és tartalmaz egy grazi veret is. Feltünőnek nem mondható, ugyanakkor mindenképpen említésre érdemes, hogy a leletből hiányoznak a bécsi denárok. Az említetteken túl található még az anyagban négy db kölni, valamint egy db angol rövidkeresztes denár (short-cross penny), a 13. sz. elejéről.

A kincs összetétele klasszikusan beleillik a tatárjárás kori lelethorizontba. Keltezni a külföldi veretek alapján lehet, amelyek közül a legkésőbbiek elkészültét az 1230-as évekre helyezi az osztrák kutatás. A lelet összetétele, az elrejtés módja, a tárgyak egy része és az alapanyaguk nem szokatlan a 13. század közepére tehető, a tatárjárással összefüggésbe hozható kincshorizont leletegyütteseinek kontextusában. Általánosnak tekinthető, hogy az ékszereket és a pénzt cserépedényben rejtették el. Az ékszerek alapanyaga többnyire ezüst vagy elektron; elvétve ugyan, de egy-két aranytárgy más leletekben is elöfordul (PARÁDI 1975, 148). Az ékszerek között gyakoriak a köpüs karikák (JAKAB 2007, 249, 255-256; PARÁDI 1975, 124). Ebböl az ékszertípusból egy gyürüvel összekapcsolt, ezüst huzalból készült pár Abaújváron is elökerült (4. kép). Szintén gyakoriak a foglalatukból kivett, hegyikristály gyürü- vagy függőbetétek (PARÁDI 1975, 126, 138). Az elrejtett kincsek között nem ritkák a különböző típusú gyürük sem. Leggyakoribbak a korábbi kutatás által pecsétgyürünek vélt, liliommal, geometrikus mintával, „Agnus Dei”-vel stb. díszített, vésett fejü gyürük. Az abaújvári gyürük díszítése azonban eltér ezektől. Az egyik női gyürü aranyból készült, fején niellóból kialakított kereszt látható. A másik női gyürü ezüst, fejét geometrikus minta díszíti ugyan, ezt azonban nem vésték, hanem plasztikusan alakították ki a gyürüfejen lévő, attól eltérő színü, valószínűleg

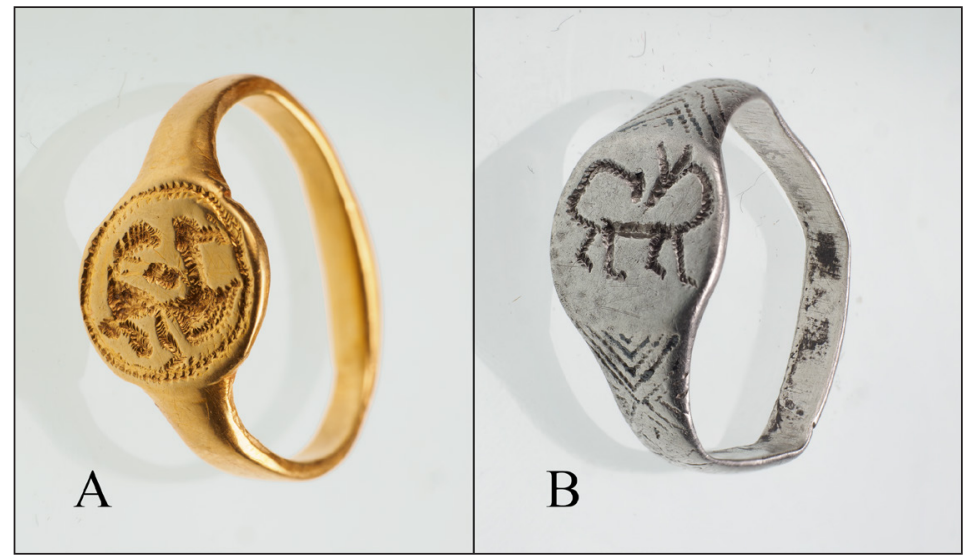

5. kép. A mitikus lénnyel díszitett férfigyürük (Gedai Csaba felvétele) szintén nielló berakáson (4. kép). A férfi gyürük közül az egyik ugyancsak arany, a másik ezüst. Fejüket bevésett állatalak díszíti. Az ezüst gyürün egy hátrafelé tekintő, felcsapott farkú állat látható. Ehhez hasonló ábrázolással, ha nem is túl gyakran, de kerültek már elő gyürük, részben temetkezésekböl, részben azonban a tatárjáráskor elrejtett kincsekből is. Az aranygyürün látható lény viszont különbözik az előzőektől, inkább hasonlít azokra a mitikus állatokra, sárkányra, griffre, vagy senmurvra, amelyekkel a korábbi kutatás az előzőekhez hasonló állatalakokat is azonosította (Rózsa \& SzIgeti, 2019, 80; 5. kép). 


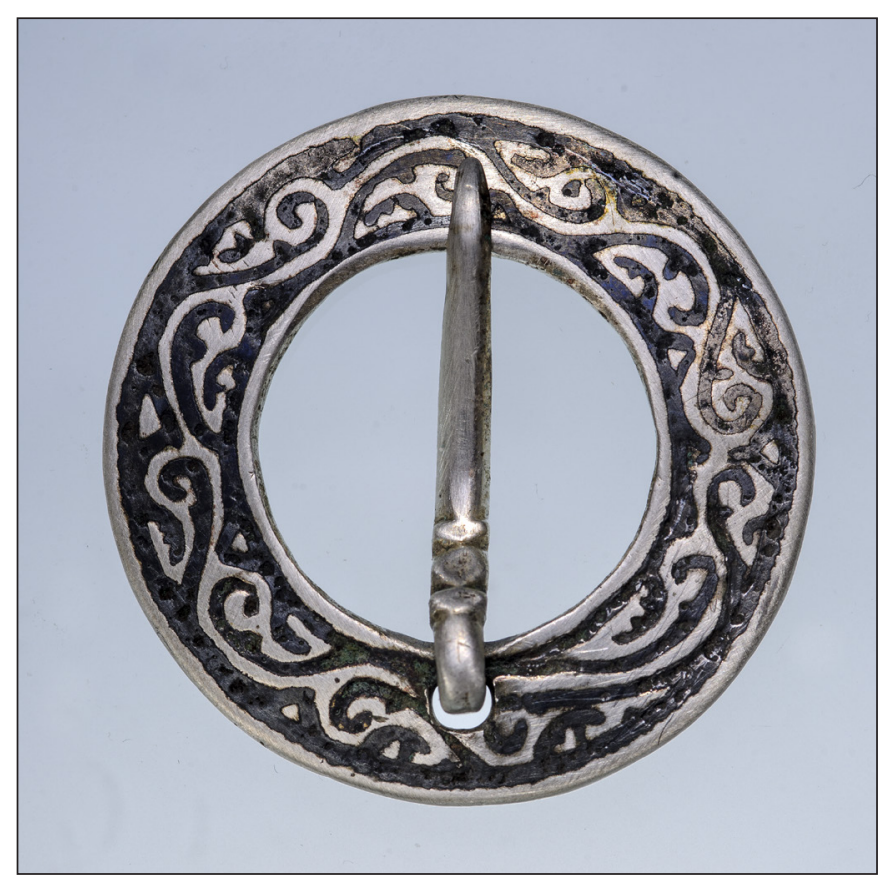

6. kép. A niellódíszes csat (Gedai Csaba felvétele)

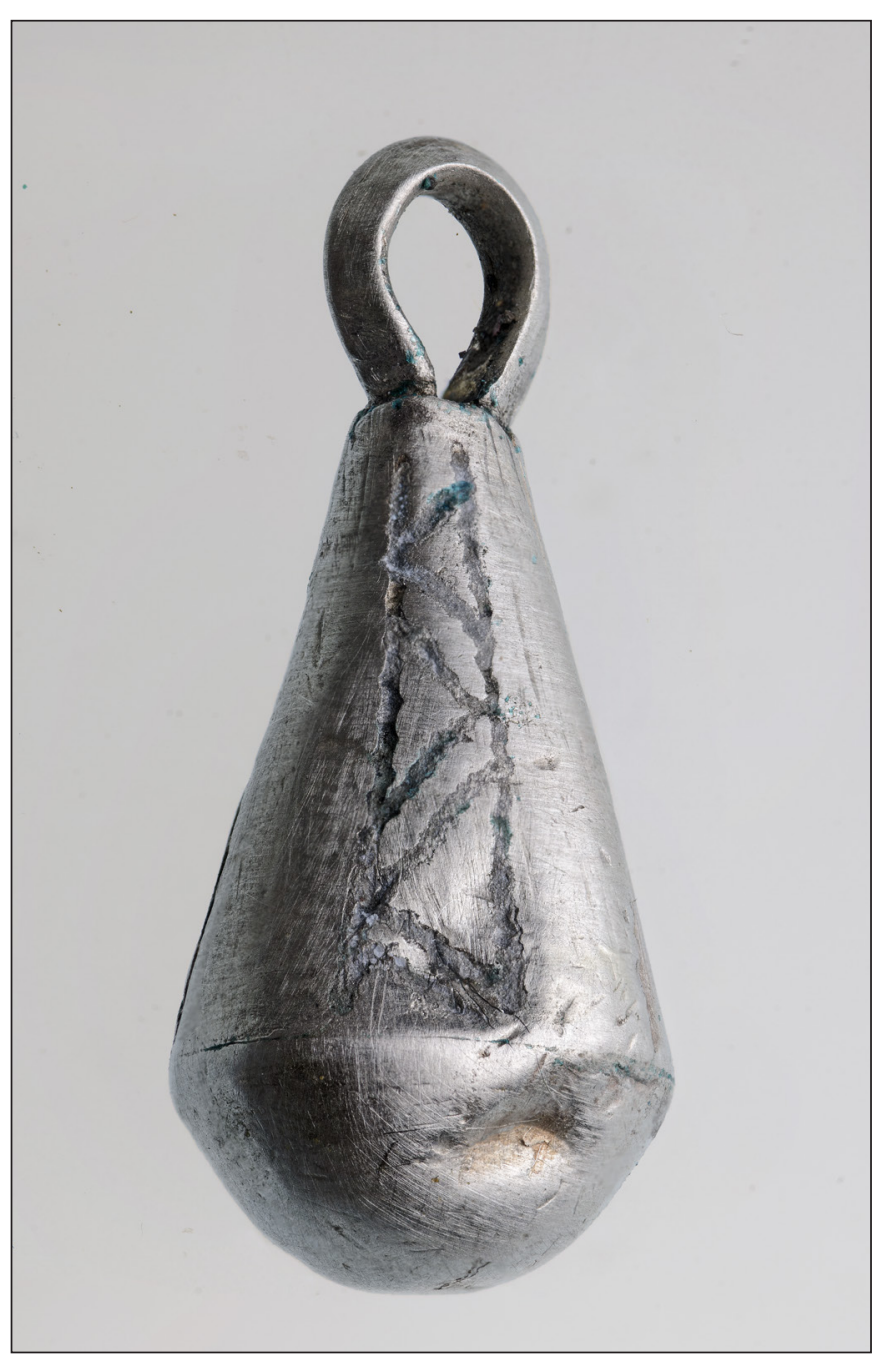

8. kép. Láncos-csüngös fülbevaló niellóval díszitett, csepp alakú csüngője (Gedai Csaba felvétele)

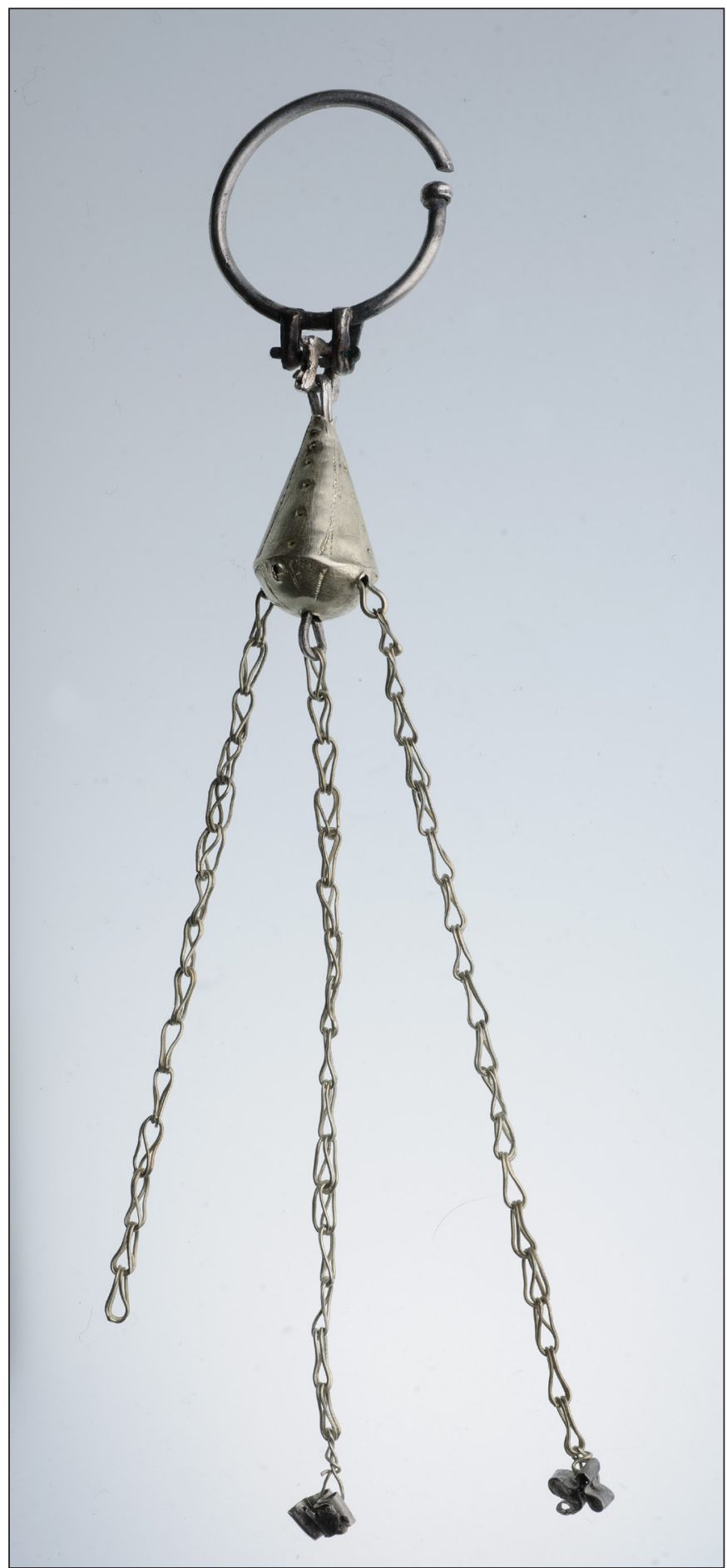

7. kép. Az ép láncos-csüngős ezüst fülbevaló (Gedai Csaba felvétele)

A kincsleletekben gyakoriak a különféle ruhaés övcsatok is. Az abaújvárihoz hasonló, niellóval díszített csatot azonban egyelöre nem ismerünk (6. kép). Igazi ritkaságnak számítanak az abaújvári kincs láncos-csüngős fülbevalói (7. kép). Míg az egyik pár teljesen ép, a másik kettőnek csak csepp alakú csüngője maradt meg (8. kép). Ez utóbbiak közül kettőt ugyancsak niellóval díszítettek. 
Bakos Gábor et al. • Tatárjárás kori kincslelet az abaújvári ispáni várból

Közvetlen párhuzamaikat idáig mindössze két lelőhelyről ismerjük: Tyukod-Bagolyvárról, tatárjáráskor elrejtett kincsből származik három láncos-csüngős fülbevaló, melyek közül az egyik arany (JAKAB 2007, 253, 11-13. kép), egy további ezüst darab pedig a kelebiai kincsben látott napvilágot (HATHÁzI 2005, 107110, 96-98. kép). A tárgytípus további párhuzamai balkáni, bizánci területekről, a mai Szerbiából, Bulgáriából, Ukrajnából és Oroszországból ismeretesek (HATHÁzI 2005, 110; JAKAB 2007, 258-259). Egyértelmünek látszik tehát, hogy e fülbevalók ezekről a vidékekről származó kereskedelmi áruk lehettek. Valószínünek tarthatjuk, hogy a többi nielló díszes tárgy, a gyürü és a csat is kereskedelmi úton juthatott el viselőjéhez. A nielló díszítés ugyanis idegen a 11-13. századi magyar ötvösmüvészettől (KIss 2007, 62, 64, 36. jegyzet; PÁlóczi Horváth 2014, 31-32).

A kincs igazi kuriózuma azonban minden kétséget kizáróan a textilmaradvány. A lelet rendkívül rossz állapotban, kiszáradva, meggyürődve, töredékesen látott napvilágot. Feltünő volt azonban, hogy a fémszálak felülete tiszta, aranyfényü maradt, nem látszott rajtuk korrózió. Ez is hívta fel rá a figyelmet fémkeresőzés közben. A restauráláskor vált világossá, hogy többféle textilmaradvánnyal állunk szemben. Az egyik egy lenvászon maradvány, amely a pénzérmékhez tapadva, kis darabkákban maradt fenn. Feltehető, hogy eredetileg ebbe a vászondarabba csomagolva rejtették a pénzeket a fazékba. A fémszálas töredékek egyike egy vászonkötésű selyemszövet maradványa, amelybe keresztben krepphatású selyem csíkokat szőttek. A csíkok egymástól 4 mm-re helyezkedtek el. A textilt mindkét hosszanti oldalán 4-4 milliméteres visszahajtással beszegték (9. kép). A fémszalag rendkívül finom, vékony volt. A természettudományos vizsgálatok ${ }^{7}$

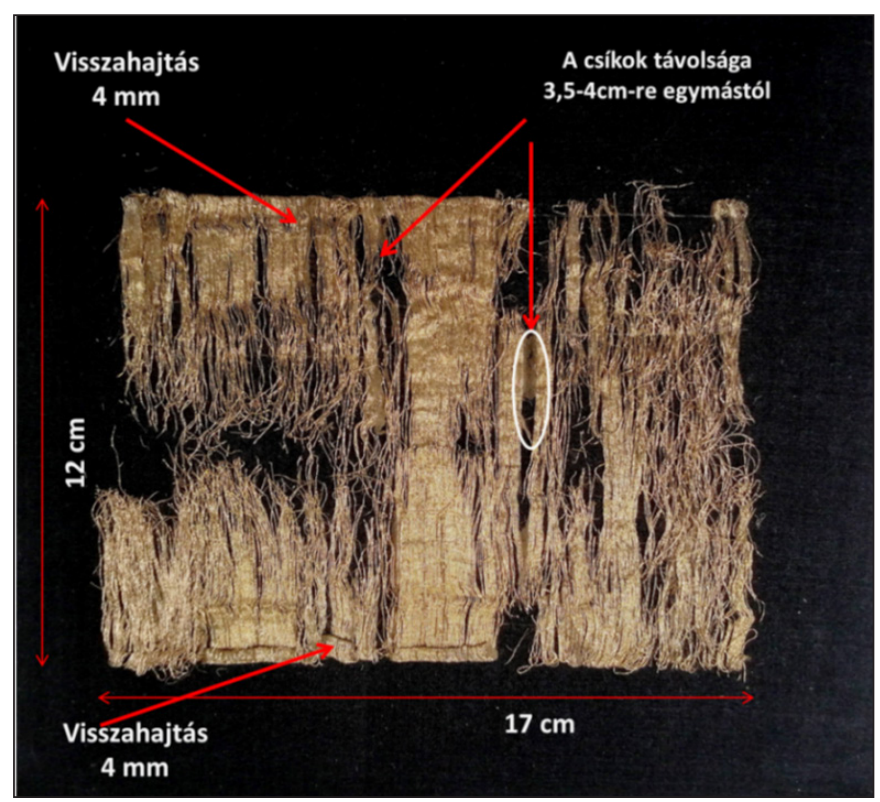

9. kép. A fejkötö kendö egyik részlete (Sipos Enikö felvétele) egyértelmüen kimutatták, hogy a fémfonalat selyem bélfonalra fonták, magát a fémszalagot pedig vékony, egy oldalán aranyozott ezüst lemezből vágták ki, ollóval, spirális vonalban. A másik fémszálas maradvány alapszövete sürübb, vastagabb az előzőnél, keskeny, zeg-zug vonalú, fémszálas beszövéssel, színoldalán haránt irányú, fémszálból kialakított csíkokkal (10. kép). A fémszálas textil szélessége, mindkét oldalán szegett széle és szövetszerkezete, a keresztben futó laza, kreppszerü selyem csíkokkal arra enged következtetni, hogy az elökerült maradványok egy, a korszakban gyakori női fejdísz, ún. fejkötő kendő részei lehettek. A 13. században a nők jellegzetes fejdísze volt a fejkötő kendő, amely két részből állt: a keményített vászonból lévő homlokpántból, és az alatta lévő, az áll alatt szorosan áthajtott másik vászon sávból, az ún. állszalagból. Az állszalagok szélessége 10-15 cm között váltakozott, hosszuk elérhette a 6 métert is. Fölötte viselhettek a hölgyek sapkát, koszorút, fogazott szélủ koronát. Alatta hajukat hálóba rendezhették. A fejviselethez tartozott még fátyol is, amelyet a fejkötő kendő alatt és felett is hordhattak (DAVENPORT 1948, 151. 1.)

A korszakból igen kevés textilmaradványt ismerünk hazánkból. Nagyobb töredékek idáig csak III. Béla feleségének, Antiochiai Annának a sírjából kerültek elő. Ezek egy része szintén fejdíszhez tartozott, egy aranycsipke főkötő és egy aranyszegélyes fátyol maradványa volt (Kovács 1998, 116, 3. jegyzet; SiPOS 1999, 60-68). Az újabb ásatások során Szankon sikerült kisebb, vászon kötésü szövetmaradványokra lelni (Sz. W ILHELm 2014, 85). Perkátán pedig egy aranyszállal átszőtt textilmaradványt találtak a templom körüli temető Árpád-kori periódusának egyik sírjában (HAтнÁzi \& Kovács 2014, 255, 22. kép). Nem kétséges, hogy a 13. század közepén az aranyozott ezüst szállal készült fejkötő kendő igen drága ruhadarab volt.

A vizsgálatokat Illés Levente végezte (MTA Energiatudományi Kutatóközpont Müszaki Fizikai és Anyagtudományi Intézet).

Munkáját ezúton is köszönjük. 


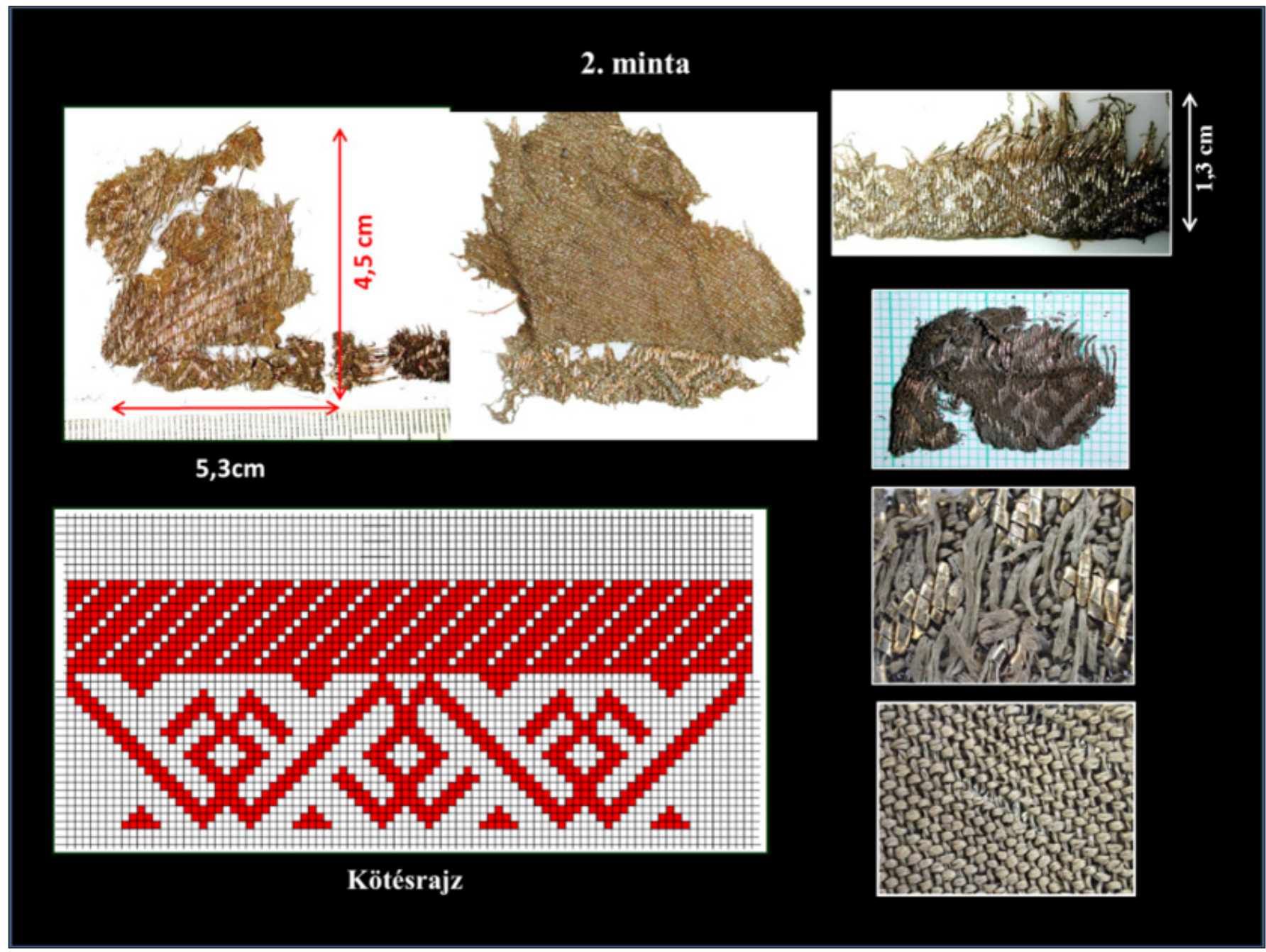

10. kép. A fejkötö kendö másik részlete (Sipos Enikö felvétele)

Erre mutat az a tény is, hogy tulajdonosa az ékszerekkel és a pénzzel együtt elrejtette. Eredetét tekintve pedig ugyancsak kereskedelmi áru lehetett, amelyet a korszak nagy textilmüves központjában, Bizáncban készíthettek.

\section{ÖSSZEGZÉS}

Kincsleletünktől nem messze, közvetlenül a vár sánca mellett egy további vasdepó, egy ekevas és három csoroszlya is napvilágot látott. Ezek, valamint a korábbi ásatáson előkerült mezőgazdasági eszközlelet arra késztet bennünket, hogy újraértékeljük Abaújvár tatárjárásban betöltött szerepét. A vár neve szerepel abban az 1242. február 2-án kelt levélben, amelyet a magyar előkelők a pápához intéztek. Ebben felsorolják azokat a magyarországi várakat, amelyek a tatárokkal szembeni ellentámadás kiinduló pontjai lehetnek (KATONA 1981, 311-313). A Dunán innen mindössze hét várat említenek név szerint, ezek között van Abaújvár is. A levélből az tünik ki, hogy Abaújvár ebben az időben Északkelet-Magyarország legerősebb vára volt. Arról azonban, hogy a tatárok ténylegesen megtámadták volna, eddig nem volt sem írásos, sem régészeti adatunk, noha a Vereckei-hágó felől érkező, Batu kán vezette hadseregnek éppen útjába esett. Az elrejtett ékszerek és pénzek, valamint a korszakban ezekkel azonos értékünek tekintett vastárgyak azonban egyértelmüen arra mutatnak, hogy a várat veszély fenyegette, lakosainak egy része elmenekült vagy meghalt, és így nem térhetett többé vissza elrejtett értékeiért. A várat ért támadást látszik igazolni az a két sír is, amelyet a templomtól és a körülötte elhelyezkedő, nagy kiterjedésü temetőtől meglehetős távolságra sikerült feltárnunk. Az egyikben gazdagon, számos verettel díszített koporsóban egy fiatal egyén nyugodott, akinek térdtől 
Bakos Gábor et al. • Tatárjárás kori kincslelet az abaújvári ispáni várból

lefelé mindkét lába hiányzott. A koporsóban egy fél pár sarkantyút is találtunk. A másik sírt közvetlenül a kincs közelében találtuk, itt egy férfit és egy gyermeket hantoltak el, szintén veretekkel díszített koporsóban. Mind a sarkantyú, mind a koporsóveretek a 13. század második felére utalnak, éppen ezért különös, hogy a megkülönböztetett figyelemmel, díszes koporsóban eltemetett halottak nem a templom körüli temetőben kaptak helyet. Valószínűleg nem tévedünk, ha a három elhunytban a tatártámadás áldozatait látjuk.

Mind az eddigi feltárások területén, mind az azokon kívül előkerült leletek arra mutatnak, hogy az abaújvári ispáni várat a tatárok megtámadták. Az írásos forrásokból és a régészeti leletek egy részéből azonban az is kitünik, hogy a vár túlélte a támadást, és a tatárokkal szembeni ellenállás egyik kiindulópontjává vált. A várbelső, és a sánc további kutatása minden bizonnyal segítene abban, hogy a vár tatárjárás kori szerepének újonnan kirajzolódó képét tisztázzuk.

\section{AJÁNLOTT IRODALOM}

Nagy, B. (szerk.) (2003). Tatárjárás. Budapest: Osiris.

Rosta, Sz. \& V. Székely, Gy. (szerk.) (2014). Carmen miserabile. A tatárjárás magyarországi emlékei. Tanulmányok Pálóczi Horváth András 70. születésnapja tiszteletére. Kecskemét: Katona József Múzeum.

Ritoók, Á. \& Garam, É. (szerk.) (2007). A Tatárjárás 1241-42. Budapest: Magyar Nemzeti Múzeum.

Laszlovszky, J., Pow, S. \& Pusztai, T. (2016). A muhi csata és az 1241-es tatárjárás. Új régészeti és történeti megközelítések. Magyar Régészet 5/7 [2016 Tél], 27-36.

V. Székely Gy. (1994). Megjegyzések a késő Árpád-kori éremleleteink keltezéséhez. In Nagy Á. (szerk.), A numizmatika és a társtudományok. Konferencia Szegeden 1993. október 25-26. (pp. 115-124). Szeged: Móra Ferenc Múzeum - Magyar Numizmatikai Társulat.

Vargha, M. (2015). Hoards, Grave Goods, Jewellery. Objects in Hoards and in Burial Contexts during the Mongol Invasion of Central-Eastern Europe. Oxford - Budapest: Archaeopress.

Wolf, M. (2001). Abaújvár. Szerk. Porkoláb A. Budapest: Száz magyar falu könyvesháza.

\section{FELHASZNÁLT IRODALOM}

Davenport, M. (1948). The Book of Costume, Feudal Lords and Kings XIII c. New York: Crown.

Gádor, J. (1980). Ausgrabung in der Erdburg von Abaújvár. Eine Kirche in der Gespanschaftsburg. Acta Archaeologica Academiae Scientiarum Hungaricae 32, 443-454.

Gádor, J. \& Nováki, Gy. (1976a). Ásatás az abaújvári földvárban. Herman Ottó Múzeum Évkönyve 15, $37-47$.

Gádor, J. \& Nováki, Gy. (1976b). Ausgrabung in der Erdburg von Abaújvár. Acta Archaeologica Academiae Scientiarum Hungaricae 28, 425-434.

Gádor, J. \& Nováki, Gy. (1980). Az abaújvári földvár sánca. Herman Ottó Múzeum Évkönyve 19, $43-77$. Györffy, Gy. (1963). Az Árpád-kori Magyarország történeti földrajza. Vol. I. Budapest: Akadémiai Kiadó. 
Bakos Gábor et al. •Tatárjárás kori kincslelet az abaújvári ispáni várból

Györffy, Gy. (1977). István király és müve. Budapest: Gondolat.

Huszár, L. (1979). Münzkatalog Ungarn von 1000 bis heute. Budapest - München: Corvina - Battenberg.

Hatházi, G. (2005). Sirok, kincsek, rejtélyek: Hires középkori régészeti leletek Kiskunhalas környékén. Kiskunhalas: Thorma János Múzeum.

Hatházi, G. \& Kovács, L. O. (2014). Árpád-kori falu és kun szállás Perkáta-Nyúli-dülő lelőhelyen. In Rosta Sz. \& V. Székely Gy. (szerk.), Carmen miserabile. A Tatárjárás magyarországi emlékei. Tanulmányok Pálóczi Horváth András 70. születésnapja tiszteletére (pp. 241-270). Kecskemét: Katona József Múzeum.

Jakab, A. (2007). Tatárjárás kori kincslelet Tyúkod—Bagolyvárról. A Nyíregyházi Jósa András Múzeum Évkönyve 49, 244-296.

Katona, T. (szerk.) (1981). A tatárjárás emlékezete. Budapest: Európa.

Kovács, É. (1998). Species Modus Ordo. III. Béla és Antiochiai Anna halotti jelvényei. Budapest: Szent István Társulat.

Kiss, E. (2007). Ötvösség és fémművesség Magyarországon a Tatárjárás idején In Ritoók Á. \& Garam É. (szerk.), A Tatárjárás 1241-42 (pp. 60-68). Budapest: Magyar Nemzeti Múzeum.

Kristó, Gy. (1988). A vármegyék kialakulása Magyarországon. Budapest: Magvető.

Müller, R. (1982). A mezögazdasági vaseszközök fejlödése Magyarországon a késövaskortól a törökkor végéig. Zalai Gyüjtemény 19. Zalaegerszeg: Zalai Megyei Levéltár.

Parádi, N. (1975). Pénzekkel keltezett XIII. századi ékszerek. A nyáregyháza-pusztapótharaszti kincslelet. Folia Archeologica 26, 119-161.

Pálóczi Horváth, A. (2014). Keleti népek a középkori Magyarországon. Budapest-Piliscsaba: Archaeolingua - Pázmány Péter Katolikus Egyetem.

Rózsa, Z. \& Szigeti, J. (2019). A kincset őrző oroszlánok: egy különleges gyürütípus a tatárjárás előestéjén. Határtalan Régészet 4/2, 78-82.

Sipos, E. (1999). Textiltöredékek Antiochiai Anna sírjából. In Cserményi V. (szerk.), 150 éve történt... III. Béla és Antiochiai Anna sírjának fellelése (pp. 60-68). Szent István Király Múzeum közleményei, B sorozat 49. Székesfehérvár: Szent István Király Múzeum.

SRH: Sriptores rerum Hungaricarum tempore ducum regumque stirpis Arpadianae gestarum. Edendo operi praefuit Emericus Szentpétery. I-II. Budapestini 1937-1938.

V. Székely, Gy. (2014). Tatárjárás és numizmatika - Egy történelmi katasztrófa pénzforgalmi aspektusai. In Rosta Sz. \& V. Székely Gy. (szerk.), Carmen miserabile. A Tatárjárás magyarországi emlékei. Tanulmányok Pálóczi Horváth András 70. születésnapja tiszteletére (pp. 331-344). Kecskemét: Katona József Múzeum.

Sz. Wilhelm, G. (2014). „Akiket nem akartak karddal elpusztítani, tűzben elégették” - Az 1241. évi 
Bakos Gábor et al. • Tatárjárás kori kincslelet az abaújvári ispáni várból

tatárpusztítás nyomai Szank határában. In Rosta Sz. \& V. Székely Gy. (szerk.), Carmen miserabile. A Tatárjárás magyarországi emlékei. Tanulmányok Pálóczi Horváth András 70. születésnapja tiszteletére (pp. 81-109). Kecskemét: Katona József Múzeum.

Tóth, Cs. (2007). A tatárjárás korának pénzekkel keltezett kincsleletei. In Ritoók Á. \& Garam É. (szerk.), A Tatárjárás 1241-42 (pp. 79-90). Budapest: Magyar Nemzeti Múzeum. 